\title{
Personal Computers: A Gateway to Personal Computing
}

\author{
Kari Kotiranta \\ Tiedetila - ScienceFarm \\ Alkulantie 265, 42930 Katajamäki, Finland
}

\begin{abstract}
This article is a personal journey, from the early days of batch processing to the modern personal computing era. The journey begins in the early 1970s and starts with the punch cards at the computer centre of the University of Jyväskylä. The use of minicomputers (HP 2100 series) gave a different view how to collect and process data with a computer. Honeywell timesharing systems made it possible to use the computer near to me, in the classroom. Early personal computers gave a feeling of freedom. In this article, I describe how the hobbyists promoted the development of computing and discuss how I took part in early software production and its use. Lastly, I briefly consider what it means to have a connection to the world using a computer at home.
\end{abstract}

Keywords: Early university computing, hobby-built computers, personal computers.

\section{Introduction}

What is personal computing? My definition of personal computing is that it must meet the following criteria: easy access to a computer, suitable applications, ease of use, and connection to the internet. This article is a personal journey from early batch processing to modern personal computing.

\section{Early Steps in Computing}

In 1970, when I started to study computer science at the University of Jyväskylä, it did not have its own central computer - only keypunch machines in the computing center where students keypunched their FORTRAN programming exercises into the cards. The punched cards were sent to a company called Valmet, which was located on the other side of the town. This company executed the programs punched into the cards and returned them to the students the following day, with a printed listing of the execution results. One of the learning materials was a book titled Tietojenkäsittely (Computing) written by Malinen [1]. In the first chapter, he writes that one needs computers to organize data and that they can be used to maintain existing systems, collect data, and design new systems [1]. It was quite an insightful beginning to computing. At that time, a computer was used for three purposes: to learn how to use a computer, to develop programs for scientific applications, and to process scientific data with statistical programs. 
In 1971, the university acquired its own Honeywell 1642, an interesting computer that had a time sharing operating system. Several terminals were placed around the university campus and computer use gained new dimensions - no longer was it necessary to go to the computer center with your punched cards, the psychology department had a terminal ready for typing. This terminal was an interactive Teletype model 33 KSR, writing on paper. For example, using a statistical software application (SURVO) was easier than the earlier work with the punched cards, because it was only necessary to answer the questions that the computer presented. Mustonen [2] developed an early version of SURVO in 1966, and the timesharing version was introduced for Honeywell at the beginning of 1970.

The presence of the terminal in the department of psychology generated new ideas about how to use the computer to add value to the department's teaching and research. For example, it was possible to create tests in which the students could respond using the computer. The problem was that there was no ready-made software for such purposes, thus researchers had to develop the programs themselves. The easiest way to program was to use the BASIC programming language. One of the first computer programs that were designed for teachers was OPSAM, which Mikkonen \& Mikkonen [3] developed to measure and analyze educational achievements. The program was a small statistical library to analyze tests - to evaluate whether the test items were relevant or not.

Five years later, Mikkonen [4] tried to analyze teaching methods using a computer program, "OVV-opetusmenetelmien vertailu ja valinta." The goal was to help teachers choose the most suitable teaching method; when the teacher should use an overhead projector, when printed materials should be distributed, and so on. His premise was that when the teacher answers questions about the content of the lecture, the computer should recognize the parameters of the teaching situation.

At the beginning of the 1970s, I was able to use another computer at the University of Jyväskylä, a HP 2116C which was situated at the Faculty of Sport Sciences. The HP 2116 computer featured an analog to digital converter and was mainly used to analyze measured data that was collected by the instrumentation recorder. The system administrator, who would thereafter input about fifty computer words one by one, using switches on the front panel, started the computer in the morning. The code entered was a BBL (Basic Binary Loader), which had to be loaded first using switches. Then the MTS (Magnetic Tape System) was loaded, and the programs and data were accessed using the magnetic tape.

During 1974 and 1975, I studied at the University of Turku that had an IBM 1130 computer that used punch cards. Some computer exercises were carried out using a HP 2100 mini-computer at the Department of Methodology. The computer had almost the same features as the HP I used in Jyväskylä, but differed in its use; instead of processing collected analog data, it was used to calculate the statistical analysis of research material.

At the University of Oulu in 1976, I again came across a Honeywell computer. Time had passed and the computer was now five years old, but there was a new terminal, a Nokia NOP 30. It was a wheel printer, which meant that it printed quality text. After a few days of experimenting, we developed a simple line editor. Although not great, the editor was better than the normal typewriter since it could at least save and print the text. 
Students had found a weakness in the Honeywell computer by creating a disk query that was very complex and then using many terminals to run the query so that the computer had no time to read and return the work within the shared four seconds limit. The result was a one-hour outage. These outages were one of the reasons to acquire a new central computer, which the University of Oulu did; it bought a UNIVAC in 1977. Students responded by writing on the bulletin board: "Bye bye Honey - welcome UNIVAC."

One phase in the history of computing in Finland ended. There had been five Honeywell computers in universities and it had been a good beginning. They were modern mainframe computers - the idea of externalized services and computing was gradually reintroduced to a wider audience with the rise of cloud computing in the early twenty-first century.

\section{Personal Computers - From Hobbyists for Hobbyists}

Byte Magazine came out in 1975 and I subscribed to it from the beginning until it published the last copy. The magazine presented the possibilities of microprocessors and even the concepts of suitable home computers. Finnish electronic journals, such as the Yleiselektroniikka and Elektroniikka magazines, were also following the trend. The year 1977 was revolutionary in personal computing; in that year, Osmo Kainulainen designed a Telmac computer construction kit for the company Telercas. He also wrote seven articles for a technical magazine, Elektroniikka, about how to build your own microcomputer and how to understand microprocessor technology [5]. At the same time Apple, Commodore, and Tandy Radio Shack presented their first home computer models. A year later, the Swedish ABC80 computer, the "'hemdator," entered the market. All of them influenced the Finnish microcomputer culture and each brand had its own fans.

I ordered a Telmac "microprocessor," as personal computers were then called, and after much soldering and assembling it was completed. The computer had an RCA 1802 processor, an RCA monitor program, a pseudo machine language, and a TinyBASIC interpreter.

A computer in your own home gave one the freedom to develop programs, play games, and do research. Until that time, the computer had always been at the end of an outgoing terminal line, with the terminal situated in the university department. Now it was on my table, and I was able to control its operation myself - it was a thrilling experience.

As an assistant in psychology, I had a lot of use for a computer. However, at that time, the tax authorities did not understand why a psychology assistant would need a computer and the related literature. "It is not widely known that a psychology assistant needs to work on a computer" was the curt reply on my application for a tax deduction.

\section{Personal Computers at Work}

The first work-related development was a piece of cross tabulation software, which was the first component of a statistical software program named PATO [6]. I also 
obtained a new tool for presenting psychological phenomena. It was possible for me to take my computer to the university so that my students could test themselves using the computer programs, which included a perception test, a reaction time test, and simple personal tests.

I proposed that personal computers should be bought for the faculty of education at the University of Oulu. This was in 1978 when the first commercial personal computers - the ABC80, the Apple II, and the Commodore Pet - were entering the market. The computer chosen was the Luxor ABC80, but purchasing a computer was not simple, because authorization was needed from the Ministry of Education. The request was made and after a few months, a purchase permit that was personally signed by the Minister of Education was on my desk.

In 1979, the first teaching experiments were carried out at the primary school of the Department of Teacher Education. The computer produced simple arithmetic tasks and provided feedback to the responses. There were two computers, which the pupils used in groups of three. While two groups at a time worked on the computers, the other students did the exercises using pen and paper. Was it effective learning? That I do not know, but everyone was eagerly involved. Teacher trainees were also interested in new teaching methods using the computer.

In the summer of 1982, I organized the first computer training courses for teachers at the University of Oulu. Some companies sponsored the courses by providing the computers, which were all BASIC programmable and there was no operating system. Programs were loaded from diskette or cassette and the teaching consisted of general information about the computers and programming exercises. Some of the teachers made simple programs for their pupils while others tried to understand how to use the computer programs.

University researchers needed statistical methods and statistical software, and creating these programs became an important development target for us. In 1982 the school board offered funding for the development of educational materials, and although I applied for resources, my request was not approved. In my disappointment, I contacted the authority to find out why my application had been refused. The answer was roughly as follows: "We are of the opinion that those micro-computers are not suitable for any real work - and therefore no money or time should be invested in them."

The first version of a statistical package for microcomputers was produced in 1982 . It was ported to nearly all microcomputer brands, including HP, Tandy, Luxor ABC, Metric, Commodore, and many others. The software was very popular in universities and other pedagogical institutes, and it was also used by some companies. We realized that it was worth the time and money to develop software for microcomputers.

Personal computers also enabled digital text processing and documentation. One of the most used categories of computer software was, and still is, word processing. It was overwhelmingly practical compared to typing with a typewriter. In the early days there were word processing machines and microcomputers with word processing software. Professional text writers used word-processing machines and researchers typed on a microcomputer. The new technology offered easier ways of writing research papers and books. 
The potential of text processing and documentation captured our interests as well. We produced the first version of the word processing software EDITO in 1982 [7]. It was one of the first text editors produced in Finland, and it became widely used by journalists and researchers. Another Finnish text editor, TEKO, was produced by Valtion Tietokonekeskus (the State Computer Centre) and used in public administration. A widely used foreign competitor was Wordstar. Many microcomputers, such as Osborne and Kaypro, had Wordstar floppy disks included.

There was no dominant operating system, which was a difficult situation for programmers. The software had to be ported to many different systems. A similar situation now exists with mobile phone operating systems; there are many different systems such as Symbian, Android, Meego, iOS, Windows Phone, and so on. When IBM introduced their Personal Computer (PC), a dominant standard was born. The IBM PC had an open architecture and anyone could create his or her own version of the IBM computer. There was DOS (Disk Operating Software), which was the same for all IBM clones. It was a godsend for programmers - only one platform for which to make software.

\section{Personal Computing for Everyone}

Old mainframe computers such as the Honeywell and Univac computers provided software for commercial and research use. They were mainly used for calculation purposes and you often needed the help of an operator to organize jobs to be carried out. It was not personal computing.

Four turning points accelerated the development of personal computers. The first was the open construction of the IBM PC in 1982. Its open specification made it possible to generate IBM clones. The second turning point was the graphical user interface, which was developed for the Xerox Alto, an early personal computer developed at Xerox PARC in 1973. Apple adopted it for Lisa in 1979 and Macintosh in 1984. In 1983, Microsoft announced the release of Windows for its own operating system (MS-DOS). The third turning point was the beginning of competition that reduced the price of personal computers; the fourth was the availability of computer programs. There were really only two platforms and it was quite easy to produce software. All of this happened before 1995.

One day in 1975, at the university cafeteria, someone voiced the idea of a global computer network. All computers would be linked and able to retrieve information from all over the world. After a moment's thought, we came to the conclusion that it would not be possible.

The first web browser, Mosaic, was developed in 1992. Local telephone companies began to sell internet connections during 1993-95. Modem connections came first, then ISDN. Now the world was open. Every home computer was able to connect to the world, thus completing the latest step for personal data processing.

Over the years, the personal computer has provided me with improvements for carrying out psychological tests and measurements, producing stimuli, and collecting data. I could use it for statistical analysis and as a teaching aid. Years ago, microcomputers developed into word processing machines. Now in 2010, personal computing is necessary for me in my everyday life at home and at work. Personal computers and personal computing have come to stay. 


\section{References}

1. Malinen, P.: Tietojenkäsittely. Werner Söderstöm Oy, Porvoo (1971)

2. Mustonen, S.: Tilastollinen tietojenkäsittelyjärjestelmä SURVO 66. Monistesarja, Moniste, no. 2, Tampereen yliopiston tietokonekeskus, Tampere (1967)

3. Mikkonen,V., Mikkonen, J.: OPSAM: Opintosaavutusten mittaus. Tammi, Helsinki (1971)

4. Mikkonen, V.: OVV-opetusmenetelmien vertailu ja valinta. Sitra, Helsinki (1975)

5. Kainulainen, O.: Mikroprosessorista 'mikrotietokoneeksi' Osa I. Elektroniikka, 13-14. Insinöörilehdet Oy (1977)

6. Kotiranta, K., Lindqvist, J.: PATO tilasto-ohjelmisto. Mikrovuo Oy, Oulu (1982)

7. Kotiranta, K., Lindqvist, J.: EDITO käsikirja. Mikrovuo Oy, Oulu (1982) 